\title{
Content and in vitro availability of iron in cooked fish commonly consumed Sri Lanka
}

\author{
I. Wickramasinghe ${ }^{1^{*}}$, K.K.D.S. Ranaweera ${ }^{1}$, U.G. Chandrika ${ }^{2}$ and A. Bamunuarachchi ${ }^{1}$ \\ ' Department of Food Science and Technology, Faculty of Applied Sciences, University of Sri Jayewardenepura, Gangodawila, Nugegoda. \\ 2 Department of Biochemistry, Faculty of Medical Sciences, University of Sri Jayewardenepura, Gangodawila, Nugegoda.
}

Revised: 13 June 2008 ; Accepted: 28 July 2008

\begin{abstract}
A study was carried out to investigate the iron content and in vitro availability of iron in four fish species namely Sardinella melanura, Sardinella albella, Carnax spp. and Exocoetus volitans by using a modified in vitro iron availability method. Iron contents were quantified in cooked fish flesh, cooked fish bones, cooking water and subsequently the in vitro availability of iron in cooked fish flesh by using atomic absorption spectroscopy. In fish species, the weight of iron was calculated on a dry weight(DW) basis. In cooked $S$. melanura, S. albella, Carnax spp. and E. volitans, the iron content in the cooked fish flesh was $335.3 \pm 6.8,322.0 \pm 6.0$, $164.8 \pm 9.3$ and $199.1 \pm 7.8 \mu \mathrm{g} / \mathrm{g}(\mathrm{DW})$, and in the bones 315.3 $\pm 6.3,155.7 \pm 10.2,101.1 \pm 8.2$ and $191.9 \pm 6.1 \mu \mathrm{g} / \mathrm{g}(\mathrm{DW})$. The iron content released to cooking water from the fish was $25.0 \pm 0.7,41.6 \pm 4.0,15.0 \pm 2.1$ and $21.0 \pm 2.4 \mu \mathrm{g} / \mathrm{ml}$ and the in vitro available iron content was $66.2 \pm 4.5,56.1 \pm 5.5,58.9$ \pm 4.4 and $72.6 \pm 3.5 \mu \mathrm{g} / \mathrm{g}$ (the latter values are expressed as a percentage reads to be $20,36,28$ and $23 \%$ ) respectively. The results showed that though the fish species studied has a high total iron content, the in vitro available iron content was much lower than the total iron content.
\end{abstract}

Keywords: Carnax spp., cooking, Exocoetus volitans, Sardinella albella, Sardinella melanura, in vitro iron availability.

\section{INTRODUCTION}

Iron deficiency results when the amount of dietary iron absorbed is insufficient to meet the iron requirement of an individual. Iron deficiency is widespread with the highest prevalence recorded in developing countries including Sri Lanka. One of the major causes of the high prevalence of iron deficiency in developing countries is the insufficient intake of dietary iron or low bioavailability of iron in the diet. According to the FAO/ WHO (1988), 4-5 billion people may be iron deficient, which corresponds to $66-80 \%$ of the world's population ${ }^{1}$. In Sri Lanka, nearly one third of the pre-school and one fifth of the primary school children are reported to be anaemic ${ }^{2}$.

The extent to which iron is absorbed from a meal depends on several factors like the individual's iron status and requirements, nature of the sources of iron, total iron content within the meal, amount of iron released and the other associated constituents of the meal ${ }^{3}$.

Sri Lanka is an island surrounded by the sea and also has a large number of inland tanks. Fish is therefore available in many areas and is a main food commodity. No study has been conducted to determine the iron content of commonly consumed Sri Lankan fish species or on their iron bioavailability. Therefore, the objective of the present study was to investigate the content and availability of iron in cooked fish using a modified in vitro iron availability method. The study focused on four fish species which are commonly consumed in Sri Lanka namely; Sardinella melanura (Salaya), Sardinella albella (Soodaya), Exocoetus volitans (Piyamassa) and Carnax (Para) spp.

\section{METHODS AND MATERIALS}

Sardinella melanura, Sardinella albella, Exocoetus volitans, and Carnax spp. were used as the fish species. Fish were purchased from fish stalls in the Colombo district. Pepsin, Pancreatin and bile extract in extra pure form (all from Sigma Chemicals, USA) were used in the study. 
Fish were identified by using their external morphological characters. Total lengths of the fish were recorded. The gills, fins and the viscera were removed and the fish was washed several times and used for the analysis.

Three replicates of $50 \mathrm{~g}$ samples were placed into separate containers and $150 \mathrm{~mL}$ of distilled water was added to each. The fish samples were cooked under regulated heat for $15 \mathrm{~min}$. The samples were then taken out and the volume of remaining water was measured. The fish flesh and bones were removed and collected separately and the weights were recorded.

The flesh and bones of the cooked fish were separated and dried at $105{ }^{\circ} \mathrm{C}$ for $48 \mathrm{~h}$ until a constant weight was obtained ${ }^{4}$. The dried flesh and bones were ground separately and were used to prepare samples for atomic absorption spectrometry.

Samples of $1.0 \mathrm{~g}$ of powdered flesh and bones of each fish species were allowed to char using an igniter ${ }^{4}$. The crucibles with the contents were transferred into a muffle furnace at $550^{\circ} \mathrm{C}$ and left until white or grey ash was obtained. The ash in each crucible was weighed. Then $1 \mathrm{~mL}$ of conc. $\mathrm{HCl}$ was added into the crucible and dissolved in $10 \mathrm{~mL}$ of distilled water. The samples were transferred into a $50 \mathrm{~mL}$ volumetric flask and made up to the mark with distilled water. The samples were nebulized into the atomic absorption spectrometer (GBC 932 plus, Australia) at $248.3 \mathrm{~nm}$ after calibrating it with standard solutions, and the total iron content was determined. The amount of soluble iron was expressed on a dry weight basis as $\mu \mathrm{g} / \mathrm{g}$.

In vitro iron availability was measured as iron solubility under physiological conditions according to the method of Svanberg et al. (1993) $)^{5}$ with some minor modifications in the initial weight of the sample. Samples of $0.5 \mathrm{~g}$ of finely mixed cooked fish flesh of each fish species were dissolved in $5 \mathrm{~mL}$ of distilled water. To this mixture, $5 \mathrm{~mL}$ of $0.3 \%$ pepsin in $0.1 \mathrm{~mol} / \mathrm{L}$ $\mathrm{HCl}$ was added. The composition of the solution to buffer the pepsin solution was prepared according to Diem and Lenther $(1975)^{6}$ and it contained physiological amounts of $\mathrm{Na}^{+}(49 \mathrm{mM}$ as $\mathrm{NaCl}), \mathrm{K}^{+}(12 \mathrm{mM}$ as $\mathrm{KCl}$, $\mathrm{Ca}^{2+}\left(10 \mathrm{mM}\right.$ as $\left.\mathrm{CaCl}_{2} \cdot 2 \mathrm{H}_{2} \mathrm{O}\right), \mathrm{Mg}^{2+}\left(2.4 \mathrm{mM}\right.$ as $\mathrm{MgCl}_{2}$. $6 \mathrm{H}_{2} \mathrm{O}$ ) and phosphate $\left(3.5 \mathrm{mM}\right.$ as $\left.\mathrm{KH}_{2} \mathrm{PO}_{4}\right)$. The $\mathrm{pH}$ was then adjusted to 2.0 with $2 \mathrm{M} \mathrm{NaOH}$ and the mixture was incubated in a shaking water bath at $37^{\circ} \mathrm{C}$ for $90 \mathrm{~min}$. After incubation, $1.5 \mathrm{~mL}$ of a pancreatin $(6 \mathrm{mg})$ and bile solution, $(37.5 \mathrm{mg})$ in $0.1 \mathrm{~mol} / \mathrm{L} \mathrm{NaHCO}{ }_{3}$ were added. The $\mathrm{pH}$ was adjusted to 5.0 with $2 \mathrm{M} \mathrm{NaOH}$, and the mixture was incubated for an additional $30 \mathrm{~min}$. After adjustment of the $\mathrm{pH}$ to 6.0 with $\mathrm{NaOH}$, the mixture was centrifuged at $4300 \mathrm{x}$ g for $20 \mathrm{~min}$. The supernatant was filtered through a $45 \mu \mathrm{m}$ filter. The $\mathrm{pH}$ in the filtrate was reduced by the addition of $200 \mu \mathrm{L}$ of $0.5 \mathrm{~mol} / \mathrm{L} \mathrm{HCl}$ to $1600 \mu \mathrm{L}$ of sample, followed by the addition of $200 \mu \mathrm{L}$ of ascorbic acid solution $(20 \mathrm{~g} / \mathrm{L})$.

After $10 \mathrm{~min}$, the samples were centrifuged (11000 $\mathrm{x} \mathrm{g}, 10 \mathrm{~min}$ ) and the clear solution obtained was analysed for soluble iron, including free soluble complexes of iron, with atomic absorption spectrometer at $248.3 \mathrm{~nm}$ (GBC 932 spectrometer). The amount of soluble iron in the filtrate was expressed as $\mu \mathrm{g} / \mathrm{g}$, dry weight (DW).

Differences in mean values of total iron content in cooked fish flesh, cooked fish bones and in vitro available iron content in triplicate samples were tested by analysis of variance (ANOVA) and significance levels were obtained with Tukey's HSD multiple range test ${ }^{7}$ and the p-value of $<0.05$ was considered significant. Simple regression analysis was done for in vitro available iron content.

Table 1: The Iron content in cooked fish flesh, fish bones, cooking water medium and the in vitro available iron content.

\begin{tabular}{llllll}
\hline Fish species & $\begin{array}{l}\text { Cooked fish } \\
\text { flesh } \mu \mathrm{g} / \mathrm{g} \\
\mathrm{DW}\end{array}$ & $\begin{array}{l}\text { Cooked fish } \\
\text { bones } \mu \mathrm{g} / \mathrm{g} \\
\mathrm{DW}\end{array}$ & $\begin{array}{l}\text { Cooking } \\
\text { water } \\
\text { medium } \\
\mu \mathrm{g} / \mathrm{mL}\end{array}$ & $\begin{array}{l}\text { In vitro } \\
\text { available iron } \\
\text { content } \mu \mathrm{g} / \mathrm{g} \\
\mathrm{DW}\end{array}$ & $\begin{array}{l}\text { Percentage of } \\
\text { in vitro } \\
\text { available } \\
\text { iron }\end{array}$ \\
\hline $\begin{array}{l}\text { Sardinella melanura (Salaya) } \\
\text { Sardinella albella (Soodaya) }\end{array}$ & $335.3 \pm 6.8^{\mathrm{a}}$ & $315.3 \pm 6.3^{\mathrm{a}}$ & $25.0 \pm 0.7^{\mathrm{a}}$ & $66.2 \pm 4.5^{\mathrm{a}}$ & 20 \\
$\begin{array}{l}\text { Exocoetus volitans (Piyamassa) } \\
\text { Carnax } \text { spp. (Para) }\end{array}$ & $199.1 \pm 7.8 \mathrm{~b}$ & $191.9 \pm 6.1 \mathrm{c}$ & $21.0 \pm 2.4 \mathrm{a}$ & $56.1 \pm 5.1 \mathrm{c}$ & 28 \\
\hline
\end{tabular}

Mean \pm Standard error of mean, $\mathrm{n}=3$; a, b, c ; Significant difference among columns were denoted by different superscripts $(\mathrm{p}<0.05)$, DW- on dry weight basis . 


\section{RESULTS}

The total iron content in the cooked fish flesh, fish bones and in the cooking water medium are shown in Table 1. In cooked fish flesh, the mean iron contents were high in Sardinella melanura and Sardinella albella with mean values in cooked fish flesh ranging from 164.8 - 335.3 $\mu \mathrm{g} / \mathrm{g}$. In cooked fish bones, the iron content ranges from $101.1-315.3 \mu \mathrm{g} / \mathrm{g}$. In the cooking water medium, the iron content ranges from $15.0-41.6 \mu \mathrm{g} / \mathrm{mL}$. The in vitro available iron content in cooked fish flesh ranges from 56 to $73 \mu \mathrm{g} / \mathrm{g}$. The mean moisture contents of cooked Sardinella melanura, Sardinella albella, Exocoetus volitans, and Carnax spp were 74\%, 75\%, 74\% and 77\% respectively.

\section{DISCUSSION}

There was a significant difference $(\mathrm{p}<0.05)$ between the mean iron contents of cooked fish flesh of the four species investigated. Higher mean iron contents were found in the flesh of Sardinella melanura and Sardinella albella being $335.3 \mu \mathrm{g} / \mathrm{g}$ and $322.0 \mu \mathrm{g} / \mathrm{g}$ respectively. There was no significant difference between the mean iron content in these two fish species.

There was significant difference between the $(\mathrm{p}<0.05)$ mean iron contents of fish bones in Sardinella melanura and Exocoetus volitans fish species. But no significant difference was found between the mean iron contents of Carnax spp. and Sardinella albella. In the case of bones, the highest mean content was observed in Sardinella melanura $(315 \mu \mathrm{g} / \mathrm{g})$.

The total iron content leached in to the cooking water medium is significantly higher $(\mathrm{p}<0.05)$ in Sardinella albella than those of Sardinella melanura, Carnax spp. and Exocoetus volitans.

As far as iron contents leached in to the cooking water medium is concerned, no significant difference was found between Sardinella melanura and Carnax spp. or Sardinella melanura and Exocoetus volitans or Carnax spp. and Exocoetus volitans.

It was observed that the amounts of iron leached in to the medium were not significant compared to the iron contents in cooked fish flesh.

There was no significant difference between the total in vitro available iron content in Sardinella melanura and Carnax spp. or Carnax spp and Sardinella albella.
But there was significant difference $(\mathrm{p}<0.05)$ between the mean in vitro available iron contents in Sardinella melanura and Sardinella albella, Sardinella melanura and Exocoetus volitans, Sardinella albella and Exocoetus volitans. However, the in vitro iron availability of these species was found to be lower compared to the iron contents in cooked fish flesh.

Fish contains relatively high amounts of readily absorbable haem iron. Haem iron is better absorbed than non-haem iron. Further, presence of cellular animal protein in fish can enhance the absorption of nonhaem iron, possibly by the formation of soluble iron complexes with L-amino acids such as cysteine as well as peptides ${ }^{9-11}$.

It is well established, however, that the adequacy of dietary iron in foods depends not only on their total iron content, but also on their bioavailability. The method used in this study is based on simulated digestion of the fish with pepsin, hydrochloric acid, pancreatin and bile salts followed by determination of the soluble iron released. Estimates of iron availability using in vitro methods generally rank similarly to those obtained in human trials ${ }^{12}$.

Although the reasons for the difference in iron contents can be many, it can be assumed that one reason for the high iron content in Sardinella melanura flesh may be due to the smaller bones in the flesh. Within these fish species there were significant differences $(p<0.05)$ between the mean iron contents of fish flesh

It has been reported in previous studies that, the nutritional composition of fish muscles varies from one season to another, species to species and within a single species as well ${ }^{13}$. In addition, environmental factors too contribute to the concentration of metal in fish. This view has been supported by the findings of Window et al. ${ }^{14}$ and Khan et al. ${ }^{15}$, which showed that variations in the concentrations of elements from one sample of fish to another was due to the chemical forms of the elements and their concentration in the local environment.

In cooked fish bones, the highest mean iron content was observed in Sardinella melanura and the mean iron content ranges from 101.1-315.3 $\mu \mathrm{g} / \mathrm{g}$ and in cooking water medium, the leached iron content ranges from 15 to $42 \mu \mathrm{g} / \mathrm{mL}$ in the studied fish species. 


\section{CONCLUSION}

In Sardinella melanura and Sardinella albella higher amount of iron was observed in both fish flesh and fish bones than in Carnax spp. and Exocoetus volitans. The in vitro iron availability of Sardinella melanura, Sardinella albella, Exocoetus volitans and Carnax spp. were $20 \%, 23 \%, 28 \%$, and $36 \%$ respectively. Although there was a considerable amount of iron in these fish species the in vitro iron availability was lower. The amounts of iron leached into the cooking medium were not high and therefore substantial amounts of total iron were retained in fish flesh. However, it is recommended the gravy in a fish curry along with the fish flesh be consumed in order to increase the amount of the available iron in the portion consumed.

\section{Acknowledgement}

Financial assistance by the Research Promotion Centre, University Grants Commission (Research grant no; $\mathrm{RPC} / 2005 / 2 \mathrm{i} / 01 / \mathrm{SJP})$ is gratefully acknowledged.

\section{References}

1. FAO/WHO. (1988). Requirements of Vitamin A, iron, folate and vitamin B12: Report of a joint FAO/WHO, Expert Consultation, FAO, Rome.

2. Medical Research Institute, Sri Lanka. (2001). Report of the Survey on the Assesment of Anemia Status in Sri Lanka, Ministry of Health Nutrition and Welfare, Colombo.

3. Bothwell T.H, Charlton R.W., Cook J.D. \& Finch C.A. (1989). Iron Absorption and iron metabolism in Man. Blackwell Scientific Publications. London pp. 256-283.

4. AOAC. (2000). Official methods of Analysis of AOAC International $17^{\text {th }} \mathrm{ed}$. AOAC International , Gaithersburg, MD, USA, Official Method 938.08.

5. Svanberg U., Lorri W. \& Sandberg A.S. (1993). Lactic fermentation of non-tannin and high-tannin cereals: Effects on In vitro estimation of iron availability and phytate hydrolysis. Journal of Food Science. 58(2):408412.

6. Diem K. \& Lenther C. (1975). Scientific Tables. $7^{\text {th }}$ ed.: Ciba-Geigy Ltd. Basel, Switzerland. 810 p.

7. Wilkinson L. (1990) SYSTAT: The system for statistics. IL, SYSTAT Inc. Evanton.

8. Ako P.A. \& Salihu S.O. (2004). Studies on some major and trace metals in smoked and oven dried fish. Journal of Applied Sciences and Environmental Management 8(2): 5-9.

9. Perlas L.A. \& Gibson R.S. (2005). Household dietary strategies to enhance the content and bioavailability of iron, zinc and calcium of selected rice and maize based Philippine complementary foods. Maternal and Child Nutrition 1(4): 263-273.

10. Taylor P.G., Torres M.C., Romano E.L. \& Layrisse M. (1986). The effect of cysteine- containing peptides released during meat digestion on iron absorption in humans. American Journal of Clinical Nutrition 43 (1): 68-71.

11. Sandstrom B., Almgren A., Kivisto B. \& Cederblad A. (1989). Effect of protein level and protein source on zinc absorption in humans. Journal of Nutrition 119(1): 48-53.

12. Rao B.S.N. \& Prabhavathi T. (1978). An in vitro method for predicting the bio availability of iron from foods. American Journal of Clinical Nutrition 31(1):169 -175.

13. Burgress G. H.O., Cutting C. L., Lovern J.A., \& Waterman J.J. (1965). Fish handling and processing. Tory Research Station, Ministry of Technology, Edinburg, Her Majesty's Stationary Office, London. pp. 90-101.

14. Window H., Stein D., Sheldon R. \& Smith R. Jr. (1987). Comparision of trace metal concentrations in muscle of a benthopelagic fish (Coryphaenoides armatus). From the Atlantic and Pacific oceans. Deep Sea Research 34 (2): $213-220$

15. Khan A.H., Ali M., Biaswas S.K. \& Hadi D.A. (1987). Trace elements in marine fish from the Bay of Bengal. The Science of the Total Environment. 61(1): 12 - 130. 